\title{
Cần thắt chặt chi tiêu trong mùa dịch
}
¿ sciencevietnam
E Cuộc sống
(1) September 20, 2021

SSHPA (20-09-2021) — Trong 8 tháng đầu năm 2021, số lượng xe nhập khẩu đã tăng mạnh 95,6\% so với năm ngoái [1]. Đây là con số lớn nếu xét trong bối cảnh dịch bệnh khó khăn hiện nay.

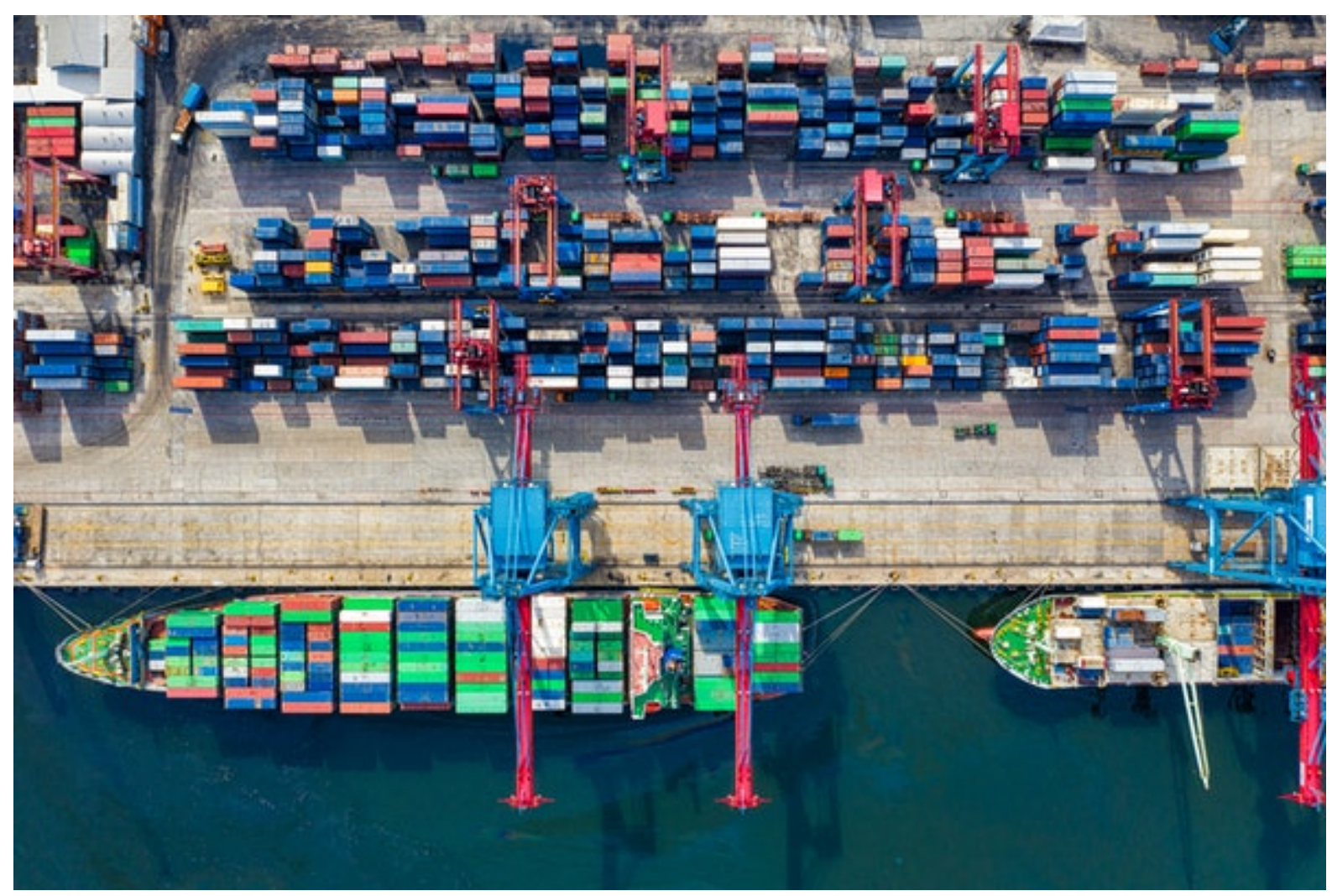

(Ảnh của Tom Fisk từ Pexels)

Trong giai đoạn dịch bệnh vừa qua, các cảng biển đều tránh nhập khẩu hàng do quá tải. Nhân lực tại cảng cũng giảm đáng kể do dịch bệnh [2]. Tình trạng này thực tế khá phổ biến trong điều kiện hiện nay. Thậm trí, có nhiều cảng trên thế giới còn đã phải tạm dừng hoạt động.

Mặc dù chưa có thống kê chính xác nhưng sự gia tăng của việc nhập khẩu một mặt hàng tiêu dùng ôtô giữa mùa dịch bệnh cho thấy nhu cầu chi tiêu của người dân vẫn rất cao. Điều này thực tế cũng tương đồng với giai đoạn nền kinh tế bất ổn vào đầu năm 2008, khi "giá trị nhập khẩu ôtô nguyên chiếc của 8 tháng đầu năm 2008 vẫn tăng hơn 300\% so với cùng kỳ 2007" [3].

Đợt dịch COVID-19 thứ 4 tại Việt Nam hiện nay đã kéo dài gần 5 tháng (27/4 tới nay). Khác với các đợt dịch trước, người dân đã thực hiện giãn cách xã hội đầy quyết 
liệt để có thể sớm dập dịch. Tuy nhiên, quá trình đóng cửa kéo dài rõ ràng sẽ để lại những hệ quả khó đoán cho nền kinh tế. Vì vậy, việc tiết kiệm chi tiêu hiện nay là rất cần thiết.

\section{Tài liệu tham khảo:}

[1] Văn T. (2021). 8 tháng, ô tô nguyên chiếc nhập khẩu tăng 95,6\%. Kinh tế và Dự báo. URL: https://kinhtevadubao.vn/8-thang-o-to-nguyen-chiec-nhap-khautang-956-19369.html

[2] Gia V. (2021). Doanh nghiệp logistics, dịch vụ xuất nhập khẩu gặp khó. Báo Đồng Nai. URL: http://baodongnai.com.vn/kinhte/202108/doanh-nghiep-logistics-dichvu-xuat-nhap-khau-gap-kho-3072497/

[3] Chính PM, \& Hoàng VQ. (2021). Kinh tế Việt Nam: Thăng trầm và đột phá. Nxb Chính trị Quốc gia Sự thật, Hà Nội.

\section{(1) Last modified: 9/20/2021 5:05 PM $\quad$ OViews: 3 f 0 \% 0}

\section{Bài liên quan:}

- Ngẫm về chi phí và tổn thất kinh tế do Covid-19

- Truyền thông khoa học trong thời kỳ COVID-19

- Hiệu quả của các vaccine phòng COVID-19 trước biến thể Delta (B.1.167.2)

- Tại sao biến thể Delta của virus SARS-CoV-2 lại lan nhanh?

- Vaccine Sputnik của Nga cho thấy hiệu quả

\section{Ý kiến bạn đọc (0):}

Comment

\section{Gửi bình luận}

(c) 2018 - 2021 EASE Vietnam SciComm System. All rights reserved. Powered by Vuong \& Associates. Built to serve the social sciences and humanities. 